\title{
A typology for the categorisation of ethical leadership research
}

Author:

Prof Charlotte Pietersen ${ }^{1}$

\section{Affiliation:}

${ }^{1}$ University of Limpopo,

Polokwane, South Africa

E-mail:

charlotte.pietersen@ul.ac.za

DOI:

$10.15249 / 12-2-153$

\section{Keywords:}

research typology; ethical leadership; theoretical; systematic; narrative; action research

\section{Abstract}

The article introduces an expanded typology of research approaches applicable to the field of ethical leadership, namely: theoretical-integrative, systematic-analytical, narrativeinterpretive, and action-advocacy. An illustrative review identified clear examples of this framework for categorising types of research on ethical leadership. It is concluded that the investigation shows the applicability of a more nuanced perspective on research in the field of ethical leadership. The analysis provides support for the use of the typology beyond the customary quantitative and qualitative dichotomy.

\section{Introduction}

The term ethics refers to sets of standards or value-driven rules governing human behaviour (Racelis, 2010). In the Western tradition, the discussion of ethics dates back to Plato (427-347 B.C.) and Aristotle (384-322 B.C.) (Vogel, 2012). The term is derived from the Greek word ethos meaning conduct, character or custom. An early, but comprehensive, literature review demonstrates that ethics is studied in various disciplines (Ciulla, 1995). It has also been an enduring topic for speculation and research in various management disciplines and in organisational studies (Ciulla, 1995; Halisa, Akovab \& Tagrafc, 2007; Proios, Athanailidis \& Arvanitidou, 2009). It can be concluded that although ethics has its origin in ancient times, it continues to touch all spheres of life and human activity, including the business world (Takala, 2012). It is characterised by a comprehensive body of literature that reflects the use of diverse conceptual and methodological approaches. There has also been an unprecedented upsurge of interest in ethics 
within various business contexts (Copeland, 2014; Jones, 2015; Heres \& Lasthuizen, 2012) as a result of a number of devastating business and corporate scandals, for example Steinhoff, Worldcom, Enron, and Lehman Brothers.

In the present investigation, the nature of research and published scholarly literature pertaining to the field of ethical leadership is highlighted by way of illustrative examples. Within the broad field of business ethics particular emphasis has been placed on the central role of ethical leadership in organisations (Bishara \& Schipani, 2009; Hannah \& Zatzick, 2007; Ncube \& Wasburn, 2006; Palmer, 2013). Kasthuri (2009), as well as Brewster, Carey, Grobler, Holland and Warnich (2008), regard ethical leadership as one of the fundamental challenges of our times. Schoeman (2014) believes that no organisation can be ethical if its leaders are not. Ethical leadership is regarded as a key resource that can either be an asset or a hindrance in shaping behaviour in organisations, in achieving long-term organisational success, and in optimising the competitive advantage of business (Zain-Ul-Aabdeen, Khan, Khan, Farooq, Salman \& Ruzwan, 2016). Therefore, the ethical dimension of leadership has been and continues to be a major topic of interest for researchers around the world (Lawton \& Pảez, 2015).

It is customary to divide methodological approaches employed in organisational and business management research into quantitative and qualitative approaches (Bryman, 2004; Bryman \& Bell, 2015). Scholars, amongst them Stentz, Clark and Matkin (2012), also recommend the use of a combination of the two approaches into mixed-method designs in leadership research. Reviews of the literature have shown that these two basic methodological traditions, as well as combinations of the two, have also been used in ethical leadership research (Monahan, 2012).

However, early on, scholars such as Alvesson (1996) expressed dissatisfaction with these conventional approaches to leadership research. Although it is convenient to use the qualitative-quantitative dichotomy, the distinction between the two types of research is very broad and does not allow a more nuanced distinction between research approaches (Allwood, 2012; Parry, Mumford, Bower \& Watts, 2014). Janićijević (2011) believes that the understanding of a complex phenomenon could be enhanced by employing a wider array of methodological approaches.

The present study focuses on the nature of ethical leadership research beyond what is usually referred to as quantitative and qualitative designs. The aim of the study is to perform a typological analysis of research in the field of ethical leadership to expand the range of research methodological applications. A framework of four basic modes of obtaining knowledge is proposed for analysing the nature of ethical leadership research. This approach provides a broader framework for identifying more distinctive methodological options to the study of ethical leadership. It has not previously been used to categorise research in this field. However, it has been successfully applied before in analysing research trends in Human Resource Management (C. Pietersen, 2016) and in organisational culture (Pietersen, 2017), and in considering the nature of knowledge development in the discipline of Industrial/Organisational Psychology (Pietersen, 2005). 


\section{Ethical leadership}

In contrast to other type of contributions (e.g. philosophical, sociological, business management) to what is generally referred to as the field of 'business ethics', leadership ethics is an applied field of ethics (Ciulla, 2005) that typically focuses on behavioural or psychological aspects. Enderle (1987:669) highlights the importance of the ethical dimension of managerial behaviour, which, for him, amounts to "responsible leadership in complex situations". Yukl (2006), as well as Mihelič, Lipičnik and Tekavčič (2010), regard the concept of ethical leadership as an ambiguous construct consisting of various diverse elements. In the leadership literature there seems to be a lack of clarity as to how to define and measure the concept (Yukl, Mahsud, Hassan \& Prussia, 2013). In general, ethics provide individuals and groups with a system of rules or principles which serve as guidelines for making decisions about what is right and what is wrong in a given situation (Northouse, 2010). When applied to leadership, ethics is about the character of leaders/managers and their actions and behaviours. The most well-known and frequently used definition of ethical leadership is formulated by Brown, Treviño and Harrison (2005:120). They describe the concept as: “...the demonstration of normatively appropriate conduct through personal actions and interpersonal relationships, and the promotion of such conduct to followers through two-way communication, reinforcement and decision-making".

More recent views of ethical leadership (De Hoogh \& Den Hartog, 2008; Yates, 2014) propose that ethical leadership is related to leaders' ability to consistently base their decisions and behaviour on relevant moral values, norms, rules, and obligations, as well as their ability to cultivate ethical decision making and behaviour amongst their followers/ subordinates. Brown and Treviño (2006) reviewed the ethical leadership literature, linking it more broadly with the concepts of spiritual, authentic and transformational leadership. They also discuss the influence of individual behavioural aspects such as personality and motivation, and outcomes of ethical leadership such as employee pro-social behaviour, ethical decision making by followers, follower work attitudes, and employee counterproductive behaviour.

The findings of a recent literature review of ethical leadership by Monahan (2012) also show that the concept is complex and a relatively new area of study. In addition, her study reveals four main topics on which researchers have tended to focus, namely, the definition of ethical leadership, the personal integrity and morality of a leader, how a leader ethically influences followers, and current challenges facing ethical leaders (2012:56). Resick, Hanges, Dickson and Mitchelson (2006) compare the degree to which four aspects of ethical leadership, namely, character or integrity, altruism, collective motivation, and encouragement, are regarded across cultures as important for effective leadership. They found that each of these dimensions varied significantly amongst cultures. Plinio (2009) summarised research that shows that there is a global need for ethical leadership. He reports that ethical misconduct in general remains high; employees do not report unethical conduct for fear of reprisal; and that the number of companies reporting the successful establishment of an ethical organisational culture 
has declined. His solution is: ethical leadership at the top; supervisor reinforcement; peer commitment to ethics; and embedded ethical values in businesses. Copeland (2014), in turn, reviews the literature in terms of what she describes as "values-based leadership" and identifies three core constructs, namely, authentic leadership, ethical leadership, and transformational leadership. She recommends research that cultivates, develops and measures values-based leadership.

In sum, the ethical leadership literature has substantially increased over the past few decades with increasing attention to various antecedents and consequences, as well as its empirical relationship with other workplace and organisational behaviours.

\section{Approaches to ethical leadership research}

Various terms have traditionally been used to distinguish between what is now generally described as quantitative and qualitative research. Robson (2011), for example, uses the terms positivist/objectivistic instead of quantitative, and interpretive/subjectivistic to refer to qualitative research. Although earlier research findings about ethical leadership are largely anecdotal and normative in nature (Brown \& Treviño, 2006), the use of quantitative (mainly hypothesis-testing) designs has come to dominate research on ethical leadership (Hodgson, Green \& Kodatt, 2012). Plinio, Young and Lavery (2010), as well as Darcy (2010), Marsh (2013) and Resick, Martin, Keating, Dickson, Kwan and Peng (2011) studied ethical leadership from a qualitative perspective. Other scholars, such as Ekaningtias (2016); Kacmar, Andrews, Harris and Tepper (2013); Obicci (2015); and Ruiz-Palomino, Saez-Martınez and Martınez-Canas (2013) investigated the relationship between ethical leadership, individual-level employee behaviour work outcomes, as well as groupand organisational-level variables (such as organisational culture) from a quantitative perspective. Yang, Ding and Lo (2016), for example, investigated the relationship between ethical leadership and multidimensional organisational citizenship behaviours. Zhu (2008) conducted research on psychological empowerment as an underlying influence mechanism through which ethical leadership affects followers' moral identity. Selart and Johansen (2011) studied the relationship between ethical decision making and leadership stress. Shin (2012) investigated the relationship amongst a number of variables, including ethical leadership, ethical climate and organisational citizenship behaviour.

Quantitative research has also been conducted to develop measures of ethical leadership or to relate the concept to existing psychometric tests. Questionnaires to assess aspects of ethical leadership, as well as ethical decision making in the work context, have been developed and/or validated by, amongst others, Boshoff, Kotzé and Nel (2014), Chikeleze (2014), Kalshoven, Den Hartog and De Hoogh (2011a), and Yukl, Mashud, Hassan and Prussia (2013). In addition, Kalshoven et al. (2011b) investigated the association between ethical leader behaviour and the Big Five Factors of Personality, while scholars, such as De Hoogh and Den Hartog (2008), employed a multi-method design to investigate the relationship between leaders' social responsibility and various aspects of ethical leadership. Mayer, Kuenzi and Greenbaum (2010), criticise the current abundance of quantitative research on the associations between ethical leadership and other manifestations of 
employee behaviour. It is also proposed that more research is needed to address the lack of rigorous, theory-based studies of ethical leadership (Brown \& Treviño, 2006), as well as the development of models dealing with the implementation of interventions to develop ethical leadership in businesses, in order to enhance leaders' ethical performance, and to find solutions for ethical leadership dilemmas in organisations (Monahan, 2012; Smit, 2013; Webley \& Werner, 2008).

\subsection{Basic orientations to knowledge development}

H.J. Pietersen $(2005,2016)$ discusses a variety of approaches to knowledge development that have been evident in the history of scholarship. He explains how this has resulted in a number of basic and interconnected orientations or modes of understanding that typically underpin and shape the products of the human intellect, across a diverse range of disciplines and bodies of knowledge. Based on these insights he developed a fourfold framework of interrelated fundamental knowledge orientations. He formulated a number of propositions central to this framework. The first proposition is that clearly recognisable, underlying orientations of mind govern different ideas, theories, and ways of making sense of and dealing with the world. Proposition two suggests that there is a dynamic tension of conflict and complementarity between co-existing orientations in the framework. The third proposition holds that individual or collective thought products bring to light different mixes of the basic orientations, even though dominant (primary) tendencies exist as a result of core predispositions. This implies that no thinker/scholar functions exclusively within a single mode of thought. Thinkers/scholars could also interface with the other modes of thought. Thus, in the present context, ethical leadership theorists may, for example, also engage in quantitative analyses and/or ethical improvement projects. Proposition four alludes to the idea that these underlying intellectual mind-sets appear to be universal - irrespective of whether knowledge endeavours take place in different cultures, societies, disciplines and traditions of thought, and at different levels of analysis. A further proposition specifies that the limitations of one modality of mind are complemented by the strengths of others, in particular diagonally opposite modes (Types I and III; and Types II and IV described below).

The typology of four interrelated knowledge orientations is categorised as: The Theoretical-integrative (Type I) mode, the Systematic-analytical (Type II) mode, the Narrative-interpretive (Type III) mode, and the Action-advocacy (Type IV) mode. The Type I approach to research is theoretical in nature and is predominantly associated with abstract theory-building. The Type II mode has an empirical focus and is primarily characterised by impersonal/objective scientific rationality (also known by terms such as positivism). Both the Type III mode and Type IV mode, conversely, are predominantly associated with human needs, goals and values. The aim of the Narrative-interpretive mode of knowledge is to understand and describe the meaning of phenomena. It could also be described as experiential in nature. The Action-advocacy mode is focused on the improvement of the human condition (e.g. creating a just society). In the work environment it is pragmatic in nature and geared towards interventions and the development of human potential. 
The major differentiating characteristics of each of the four types of knowledge in studies of ethical leadership are shown in Table 1.

Table 1: Four types of knowledge in ethical leadership research

\begin{tabular}{|c|c|}
\hline \multicolumn{1}{c|}{ Type I } & \multicolumn{1}{c}{ Type II } \\
\hline \multicolumn{1}{c|}{ Ethical leadership theory } & \multicolumn{1}{c|}{ Ethical leadership science } \\
\hline Aim: Conceiving ethical leadership & Aim: Explaining ethical leadership \\
\hline Mode: Theoretical-integrative & Mode: Systematic-analytical \\
\hline Ethical leadership interpretation & \multicolumn{1}{c|}{ Ethical leadership cultivation } \\
\hline Aim: Describing ethical leadership & Aim: Developing ethical leadership \\
\hline Mode: Narrative-interpretive & Mode: Action-advocacy \\
\hline
\end{tabular}

\section{Method}

\subsection{Research design}

The purpose of the present article is to introduce a more expanded typology of possible research approaches to the field of ethical leadership. Thus, the purpose of the study was not to conduct a comprehensive, full-scale review of ethical leadership research as such. The analysis was also not aimed at a critical analysis and detailed exposition of various leadership ethics models, empirical details and interpretations, as the case may be. Instead, an illustrative review was conducted and a number of articles with a primary focus on each of the four basic knowledge development orientations, was identified for inclusion as clear examples of, as well as in support of, a more comprehensive framework to categorise types of research on ethical leadership.

Databases, including FreeFull PDF, EBSCOhost Discovery, Academic Search Complete and scholar.google.com were accessed over a period of four months. Scholarly publications explicitly addressing the key search term: ethical leadership were obtained. In essence, this procedure is analogous to the one used by Monahan (2012) to examine dominant research approaches to the study of ethical leadership within a business context.

\subsection{Sampling and sample}

Purposive sampling was used to identify clear-cut examples of each of the four categories. A purposive sampling strategy is selected when selected units are judged to be typical of a population/universe of events under investigation (Bless \& Higson-Smith, 2013) and is also useful when researchers continue to add units to a sample until they judge that data saturation has been reached (Fusch \& Ness, 2015; Robson, 2011). Working back from most recent publications on the topic, a few scholarly ethical leadership articles were chosen for illustrative purposes as clearly identifiable examples of each of the four research types in terms of the framework described above. 
In other words, ethical leadership publications were included that manifestly focused on either: theory-building proposals (Type I); empirical (hypothesis-testing) research (Type II); narrative-interpretive descriptions and accounts of ethical leadership activities and experiences (Type III); or ethical leadership development and improvement research (Type IV).

\subsection{Procedures and analysis}

The data collection and content analysis procedures used in the present study are, to a large extent, based on the process used by Pisani (2009) and Pietersen (2016). Full-text (pdf) ethical leadership articles were downloaded into a folder. Each of the articles was inspected in detail in terms of the following criteria: (a) its stated aims; (b) the nature of its methodology; and (c) its conclusions, to arrive at a selection for further investigation.

An analysis was then conducted with the aid of the four-fold framework of knowledge development orientations described earlier. An article's primary focus, as demonstrated by its aim, method and reported results and conclusions, was judged to be the determining factors to decide under which one of four conceptual categories in the typological framework a specific article should be classified. Thus, the procedure consisted of a conceptual analysis of chosen publications for classification purposes.

Articles in which the primary purpose of the investigation is the construction or development of theories and models of ethical leadership are considered to be examples of Type I research. Articles which are empirical in nature and primarily focused on hypothesis-testing represent Type II research in the conventional mode of quantitative studies. Articles in which the focus is mainly on narratives (or stories) of perceptions and experiences of respondents of ethical leadership were categorised as Type III research. Articles in which the primary focus is on managing and developing ethical leadership in organisations, in terms of interventions and evaluation or policies and procedures, were judged to typify Type IV research.

The trustworthiness of data generated by means of a process of content analysis has to be addressed throughout the data analysis process. Evidence for the trustworthiness of the typological framework used in the present study is provided by the way in which results were prepared, organised and reported (as recommended by Elo, Kääriäinen, Kanste, Pölkki \& Kyngäs, 2014). See the Results section in terms of repeated cases of published research articles for each of the basic modes of research.

\section{Results}

The results of the content analysis are given by way of a convenient selection, instead of all-inclusive, number of articles deemed to be clear-cut evidentiary examples of each of the four fundamental types of research aim and design utilised in ethical leadership research. The reason for this choice is that the purpose of the presentation of the results is to provide credible support for the typological framework used in the present study. 
In doing so, a broader perspective on the nature of, and approaches to, research endeavours in the field of ethical leadership has been introduced, supported by illustrative examples.

\subsection{Type I: Ethical leadership theory}

As indicated previously, the aim in this mode of research is to conceive of and formulate inclusive models and taxonomies which, ideally, strive to produce full-blown and coherent theories of ethical leadership in organisations. Much of the attention is directed towards specifying relevant antecedents and consequences of ethical leadership. Jones (1995) proposes the character traits of the ascetic leader as the best guarantee of ethical leadership. The ascetic personality is characterised by, amongst others, self-control, self-discipline, and responsibility. This kind of leader is averse to wastefulness and to greed for its own sake, and strongly feels "... a sense of stewardship about everything in life..." (1995:868). Zhu, May and Avolio (2004) discuss the impact of ethical leadership on employees and suggest a conceptual framework that posits the psychological empowerment of employees as mediating factor between ethical leadership, employee commitment and trust in leaders. Knights and O'Leary (2006:125) recommends a “... hybrid of MacIntyre's virtue ethics and Levinas's ethics of responsibility [that] may serve as an inspiration for both educators and practitioners". Hansen (2011:42) proposes a so-called multifocal social exchange model of ethical leadership that includes attention to the moderating influence of a variety of contextual factors such as the ethical culture of the organisation, ethical predispositions, and its impact on task performance, commitment and job satisfaction (2011:42). Table 2 provides further examples of ethical leadership studies in the theoretical-integrative mode of knowledge.

Table 2: Illustrative examples of Type I research in ethical leadership

\begin{tabular}{|l|l|l|}
\hline \multicolumn{1}{|c|}{ Author(s) } & Year & \multicolumn{1}{c|}{ Description } \\
\hline Caldwell, Bischoff \& Karri & 2002 & $\begin{array}{l}\text { Proposes a Four Umpires Model of EL, concluding that the } \\
\text { Facilitating ldealist (Umpire Four) model is best. }\end{array}$ \\
\hline Palmer & 2009 & $\begin{array}{l}\text { Proposes a three-level model of different EL issues, namely: } \\
\text { individual morality, means of leadership and the leadership } \\
\text { mission itself. }\end{array}$ \\
\hline Mihelič, Lipičnik \& Teka & 2010 & $\begin{array}{l}\text { Proposes the following qualities of the ethical leader, namely: } \\
\text { thinking about long-term consequences; aiming at the greater } \\
\text { good; striving for fairness; taking responsibility, showing } \\
\text { respect; setting high ethical standards; serving as role model } \\
\text { (honest, trustworthy, courageous, demonstrating integrity). }\end{array}$ \\
\hline Eisenbeiß \& Giessner & 2012 & $\begin{array}{l}\text { Proposes an EL framework consisting of manifest and latent } \\
\text { contextual factors at three different levels of analysis: society, } \\
\text { industry, and organisation. }\end{array}$ \\
\hline Van Wart & 2014 & $\begin{array}{l}\text { Proposes a model of EL in terms of basic approaches, namely: } \\
\text { virtue (personal integrity and authentic/positive leadership); } \\
\text { deontological (moral management), and teleological (socially } \\
\text { responsible, transforming leadership). }\end{array}$ \\
\hline
\end{tabular}


The ethical leadership literature shows that, as is the case with many other management and organisational behaviour topics, the quantitative/explanatory (or hypothesis-testing) approach characteristic of the standard scientific (Type II) knowledge paradigm, is dominant. Mayer, Aquino, Greenbaum and Kuenzi (2012) tested a number of hypotheses of antecedents and consequences of ethical leadership, showing a positive relationship between ethical leadership and leader moral identity and employee work outcomes, as well as a negative relationship between "...ethical leadership and unit unethical behaviour and relationship conflict" (2012:151). Ghahroodi, Ghazaliand and Ghorban (2013) examined the impact of ethical leadership on follower work outcomes and found that where leaders are considered as role models, employees tend to have higher levels of job satisfaction and commitment, and are less inclined to leave their jobs. Onorato (2013) tested a number of hypotheses showing that unethical leadership results in workplace bullying. Yates (2014) investigated the potential of ethical leadership to foster higher levels of employee job satisfaction, organisational commitment, and organisational citizenship. Her findings show that employees led by highly ethical leaders reported greater job satisfaction and organisational commitment than did employees led by less ethical leaders. No significant difference was reported amongst employees regarding the impact of ethical leadership on their level of organisational citizenship behaviour. Köse and Köse's (2016) study of healthcare personnel reveals that ethical leadership impacts positively on employee identification with the organisation, and that ethical climate mediates ethical leadership behaviour. Table 3 provides further examples of ethical leadership studies in the systematic-analytical mode of knowledge.

Table 3: Illustrative examples of Type II research in ethical leadership

\begin{tabular}{|c|c|c|}
\hline Author(s) & Year & Description \\
\hline Zhu & 2008 & $\begin{array}{l}\text { Hypothesis-testing study }(\mathrm{N}=335) \text { of ethical leadership, } \\
\text { follower morality and psychological empowerment. }\end{array}$ \\
\hline Caldwell, Hayes \& Long & 2010 & $\begin{array}{l}\text { Hypothesis-testing study }(\mathrm{N}=296) \text { of ethical leadership, } \\
\text { trustworthiness and stewardship. }\end{array}$ \\
\hline $\begin{array}{l}\text { Kalshoven, Den Hartog \& } \\
\text { De Hoogh }\end{array}$ & 2011 & $\begin{array}{l}\text { Hypothesis-testing study }(\mathrm{N}=98) \text { of ethical leadership and the } \\
\text { big five personality factors. }\end{array}$ \\
\hline Selart \& Johansen & 2011 & Hypothesis-testing study $(\mathrm{N}=38)$ of $\mathrm{EL}$ and stress. \\
\hline Avey, Wernsing \& Palanski & 2012 & $\begin{array}{l}\text { Hypothesis-testing study }(\mathrm{N}=845) \text { of ethical leadership, } \\
\text { psychological well-being and job satisfaction. }\end{array}$ \\
\hline Shin & 2012 & $\begin{array}{l}\text { Hypothesis-testing study }(\mathrm{N}=263) \text { of ethical leadership, } \\
\text { ethical climate and organisational citizenship behaviour. }\end{array}$ \\
\hline $\begin{array}{l}\text { Kacmar, Andrews, Harris \& } \\
\text { Tepper }\end{array}$ & 2013 & $\begin{array}{l}\text { Hypothesis-testing study }(\mathrm{N}=136) \text { of ethical leadership, } \\
\text { organisational politics and political skill. }\end{array}$ \\
\hline $\begin{array}{l}\text { Ruiz-Palomino, Saez-Martinez } \\
\text { \& Martinez-Canas }\end{array}$ & 2013 & $\begin{array}{l}\text { Hypothesis-testing study }(\mathrm{N}=151) \text { of ethical leadership and job } \\
\text { motivating potential. }\end{array}$ \\
\hline Yates & 2014 & $\begin{array}{l}\text { Hypothesis-testing study }(\mathrm{N}=199) \text { of ethical leadership, job } \\
\text { satisfaction, organisational commitment and organisational } \\
\text { citizenship behaviour. }\end{array}$ \\
\hline Obicci & 2015 & $\begin{array}{l}\text { Hypothesis-testing study }(\mathrm{N}=160) \text { of ethical leadership and } \\
\text { employee performance. }\end{array}$ \\
\hline
\end{tabular}




\subsection{Type III: Ethical leadership narrative}

As the designation for this type of research indicates, narrative-interpretive studies of ethical leadership are concerned with the meaning and experiences of ethical leadership as recounted by employees in work organisations. Although this approach to human knowledge and understanding has gained a substantive following in many areas of organisational and management studies and is often referred to as qualitative research, it seems to be under-represented in the ethical leadership field, mostly as a result of the strong focus on hypothesis-testing (Type II) research (see previous section). Narrative studies of ethical leadership typically use small samples and methods such as in-depth interviews, content analyses and case studies to obtain information. Examples of this type of research are studies conducted by Darcy (2010) and Plinio, et al. (2010). In addition, Pelletier and Bligh (2008) investigated employees' reaction to the unethical behaviour of top management in their organisation and found that employees attributed the poor ethical leadership to a number of causes, such as deficient moral reasoning, breaches of trust, hypocrisy, and poor role modelling. The result was much increased levels of cynicism, pessimism and fear amongst staff. Table 4 provides further examples of the narrative-interpretive (Type III) approach to the study of ethical leadership.

Table 4: Illustrative examples of Type III research in ethical leadership

\begin{tabular}{|l|c|l|}
\hline \multicolumn{1}{|c|}{ Author(s) } & Year & \multicolumn{1}{c|}{ Description } \\
\hline Murphy \& Enderle & 1995 & $\begin{array}{l}\text { Content analysis of CEO profiles in terms of ethical leadership } \\
\text { influence on their businesses. }\end{array}$ \\
\hline $\begin{array}{l}\text { Resick, Martin, Keating, } \\
\text { Dickson, Kwan \& Peng }\end{array}$ & 2011 & $\begin{array}{l}\text { Interview content analysis of the meaning of EL for managers } \\
\text { in six societies. }\end{array}$ \\
\hline Koning \& Waistell & 2012 & $\begin{array}{l}\text { Metaphor analysis of Chinese managerial narratives to } \\
\text { determine EL aspirations. }\end{array}$ \\
\hline Marsh & 2015 & $\begin{array}{l}\text { Interview content analysis of perceptions of EL by business } \\
\text { executives. }\end{array}$ \\
\hline Jones & $\begin{array}{l}\text { Phenomenological interviews of EL practices of Fortune } 500 \\
\text { leaders. }\end{array}$ \\
\hline
\end{tabular}

\subsection{Type IV: Ethical leadership development}

Ethical leadership research in the action-advocacy (Type IV) mode is concerned about programmes and activities for cultivating and improving ethical leadership in organisations. The focus is on what actions can be taken to improve the ethics situation, especially as regards leader values, policies and conduct. Whereas ethical leadership research in the other three modes of knowledge provides often detailed information and quantitative analyses of various ethical leadership concepts and its organisational antecedents and consequences, Type IV research is concerned with application and betterment of the situation in the workplace and with evaluating ethical improvement intervention efforts. Adobor (2006) discusses the role of corporate ethics officers, concluding that persons with certain competencies and approaches are better suited to this position. Moreno (2010) discusses the managerial responsibility for ethical 
communication and proposes a number of aspects for improving ethical leadership, namely: communicating with integrity, to the right people at the right time and place. Abrhiem (2012) discusses the moral development of leaders and how they can retain their ethical values in different business environments. Table 5 provides further examples of ethical leadership scholarship in the action-advocacy mode of knowledge.

Table 5: Illustrative examples of Type IV research in ethical leadership

\begin{tabular}{|l|c|l|}
\hline \multicolumn{1}{|c|}{ Author(s) } & Year & \multicolumn{1}{c|}{ Description } \\
\hline Ncube \& Wasburn & 2006 & $\begin{array}{l}\text { Outlines a mentoring framework for promoting ethical } \\
\text { decision making by managers. }\end{array}$ \\
\hline Webley \& Werner & 2008 & $\begin{array}{l}\text { Recommends EL requirements in terms of organisational } \\
\text { policies, process and practices. }\end{array}$ \\
\hline Bishara \& Scipani & 2009 & $\begin{array}{l}\text { Outlines a programme for the detection, prevention and } \\
\text { eradication of corrupt leadership practices. }\end{array}$ \\
\hline Kasthuri & 2009 & $\begin{array}{l}\text { Recommends a programmatic framework for improving } \\
\text { EL practices in organisations. }\end{array}$ \\
\hline $\begin{array}{l}\text { Beeri, Dayan, Vigoda-Gadot } \\
\text { \& Werner }\end{array}$ & $\begin{array}{l}\text { Evaluation of the impact of an ethics programme on } \\
\text { employees. }\end{array}$ \\
\hline
\end{tabular}

\section{Conclusion}

It is believed that the aim of the investigation, namely to introduce a broader, more nuanced, typology of research in the field of ethical leadership and to contribute to existing knowledge by expanding the range of such research efforts, has been met. The discussion provides support for the use of the typology to achieve a finer distinction amongst research endeavours conducted in the field and to augment the customary quantitative and qualitative dichotomy in ethical leadership research. All four basic modes are evident in ethical leadership thought, research and practice.

Research published in the Type I mode of understanding gives evidence of the theoreticalintegrative pursuit to develop all-inclusive ethical leadership theories and models. Type II research typically employs the hypothetico-deductive method. Type III research is analogous to traditional qualitative research. It is focused on reconstructing and describing the meaning and lived experiences of ethical leadership. A range of various methods (for example, in-depth, unstructured interviewing, case studies, content analysis, and metaphor descriptions), traditionally associated with the qualitative paradigm, are used in this mode of research. Type IV research is focused on empowering leaders to be more ethical. The purpose of this mode of research is to develop and evaluate interventions, activities and programmes aimed at developing, influencing and changing the nature of ethical leadership to enhance the congruence between the practice of ethical leadership and a healthy and productive organisational environment.

The study provides a good indication of the appropriateness of the paradigmatic framework for classifying research in the field of ethical leadership. It is recommended that the typology be considered by ethical leadership scholars and researchers for the purpose of further knowledge development in the field of study. Managers and 
practitioners could also broaden their horizons by taking cognisance of the idea that research on ethical leadership could be conducted, not only by using a preferred (and traditional) modality, but also by considering and employing multiple modalities.

The use of a small sample could be regarded as a limitation of the study. However, the focus of the present article was merely to provide illustrative examples of each of the four types of research in the field of ethical leadership. In view of the aim of the article, this is not regarded as a serious limitation, as long as clear examples of each of the four knowledge development orientations that shape the products of the human intellect have been provided.

Lastly, the use of the typology of four interrelated knowledge orientations to analyse ethical leadership research provides a broadened perspective on the nature of different approaches to studying and understanding in this field of interest. This could assist in expanding scholarly horizons and should provide a more rounded perspective on the nature of enquiry and study in the field.

\section{References}

Abrhiem, T.H. (2012). Ethical leadership: keeping values in business cultures. Business and Management Review, 2(7):11-19. http://www.businessjournalz.org.bmr [Accessed 12 November 2016].

Adobor, H. (2006). Exploring the role performance of corporate ethics officers. Journal of Business Ethics, 69:57-75. https://doi.org/10.1007/s10551-006-9068-7

Allwood, C.M. (2012). The distinction between qualitative and quantitative research methods is problematic. Qualitative Quantitative, 46:1417-1429. https://doi.org/10.1007/s11135-011-9455-8

Alvesson, M. (1996). Leadership studies: From procedure and abstraction to reflexivity and reflection. Leadership Quarterly, 7(4):455-485. https://doi.org/10.1016/S1048-9843(96)90002-8

Avey, J.B., Wernsing, T.S. \& Palanski, M.E. (2012). Exploring the process of ethical leadership: the mediating role of employee voice and psychological ownership. Journal of Business Ethics, 107:21-34. https://doi. org/10.1007/s10551-012-1298-2

Beeri, I., Dayan, R., Vigoda-Gadot, E. \& Werner, S.B. (2013). Advancing ethics in public organizations: The impact of an ethics program on employees' perceptions and behaviors in a regional council. Journal of Business Ethics, 112:59-78. https://doi.org/10.1007/s10551-012-1232-7

Bishara, N.D. \& Schipani, C.A. (2009). Strengthening the ties that bind: Preventing corruption in the executive suite. Journal of Business Ethics, 88:765-780. https://doi.org/10.1007/s10551-009-0325-4

Bless, C. \& Higson-Smith, C. (2013). Fundamentals in social research methods: An African perspective. Kenwyn: Juta.

Boshoff, E., Kotzé, M. \& Nel, P. (2014). The development and initial validation of the work convictions questionnaire (WCQ) to measure approaches to ethical decision making in the workplace: Part 2. African Journal of Business Ethics, 8(2):15-30.

Brewster, C., Carey, L., Grobler, P., Holland, P. \& Warnich, S. (2008). Contemporary issues in Human Resource Management: Gaining a competitive advantage. Cape Town: Oxford.

Brown, M.E. \& Treviño, L.K. (2006). Ethical leadership: A review and future directions. The Leadership Quarterly, 17:595-616. https://doi.org/10.1016/j.leaqua.2006.10.004

Brown, M.E., Treviño, L.K. \& Harrison, D.A. (2005). Ethical leadership: A social learning perspective for construct development and testing. Organizational Behavior and Human Decision Processes, 97(2):117-134. https://doi.org/10.1016/j.leaqua.2005.01.003 
Bryman, A. (2004). Qualitative research on leadership: A critical but appreciative review. The Leadership Quarterly, 15:729-769. https://doi.org/10.1016/j.leaqua.2004.09.007

Bryman, A. \& Bell, E. (2015). Business research methods. U.K.: Oxford University Press.

Caldwell, C., Hayes, L.A. \& Long, D.T. (2010). Leadership, trustworthiness, and ethical stewardship. Journal of Business Ethics, 96:497-512. https://doi.org/10.1007/s10551-010-0489-y

Chikeleze, M.C. (2014). Validation of the Ethical Leadership Style Questionnaire (ELSQ). Doctoral dissertation, Benedictine University, U.S.A. http://cvdl.ben.edu/home23/wp-content/uploads/2016/03/Chikelezeready-to-upload-dissertation.pdf [Accessed 12 December 2016].

Ciulla, J.B. (1995). Leadership ethics: Mapping the territory. Business Ethics Quarterly, 5(1):5-28. https://doi. org $/ 10.2307 / 3857269$

Ciulla, J.B. (2005). The state of leadership ethics and the work that lies before us. Business Ethics, 14(4):323-335. https://doi.org/10.1111/j.1467-8608.2005.00414.x

Copeland, M.K. (2014). The emerging significance of values based leadership: A literature review. International Journal of Leadership Studies, 8(2):105-135. http://works.bepress.com/marykaycopeland/1/ [Accessed 7 January 2017].

Darcy, K.T. (2010). Ethical Leadership: The past, present and future. International Journal of Disclosure \& Governance, 7(3):198-212. https://doi.org/10.1057/jdg.2010.12

De Hoogh, A.H.B. \& Den Hartog, D.N. (2008). Ethical and despotic leadership, relationships with leader's social responsibility, top management team effectiveness and subordinates' optimism: A multi-method study. Leadership Quarterly, 19(3):297-311. https://doi.org/10.1016/j.leaqua.2008.03.002

Eisenbeiß, S.A. \& Giessner, S.R. (2012). The emergence and maintenance of ethical leadership in organisations: A question of embeddedness? Journal of Personnel Psychology, 11(1):7-19. https://doi.org/10.1027/18665888/a000055

Ekaningtias, D. (2016). Effect of commitment, ethical leadership and attitude towards the performance of regional work unit in East Java Provincial Government. Human Resource Management Research, 6(2):40-44.

Elo, S., Kääriäinen. M., Kanste, O., Pölkki, T. \& Kyngäs, H. (2014). Qualitative content analysis: A focus on trustworthiness. Sage Open, January-March:1-10. https://doi.org/10.1177/2158244014522633

Enderle, G. (1987). Some perspectives of managerial ethical leadership. Journal of Business Ethics, 6:657-663. https://doi.org/10.1007/BF00705782

Fusch, P.I. \& Ness, L.R. (2015). Are we there yet? Data saturation in qualitative research. The Qualitative Report, 20(9):1408-1416. http://www.nova.edu/ssss/QR/QR20/9/fusch1.pdf [Accessed 15 November 2016].

Ghahroodi, H.K., Ghazali, M.Z.M. \& Ghorban, Z.S. (2013). Examining ethical leadership and its impacts on the followers' behavioral outcomes. Asian Social Science, 9(3):91-96. https://doi.org/10.5539/ass.v9n3p91

Halisa, M., Akovab, O. \& Tagrafc, H. (2007). The relationship between ethics and quality: Conflicts and common ground. Serbian Journal of Management, 2(2):127-145.

Hannah, D.R. \& Zatzick, C.D. (2007). An examination of leader portrayals in the US business press following the landmark scandals of the early 21st century. Journal of Business Ethics, 79:361-377. https://doi.org/ $10.1007 / \mathrm{s} 10551-007-9406-4$

Hansen, S.D. (2011). Ethical leadership: A multifoci social exchange perspective. The Journal of Business Inquiry, 10(1):41-55. https://pdfs.semanticscholar.org/78bc/c5b12ffc4fc545cbf8967630c65f26181180.pdf [Accessed 22 January 2017].

Heres, K. \& Lasthuizen, K. (2012). What's the difference? Ethical leadership in public, hybrid and private sector organizations. Journal of Change Management, 12(4):441-466. https://doi.org/10.1080/14697017.20 12.728768

Hodgson, M.N.S., Green, M.T. \& Kodatt, S. (2012). Scandal vs. suggestion: A content analysis of leadership ethics in scholarly publications versus popular newspapers and magazines. Proceedings of ASBBS, Las Vegas, 19(1):421-432. http://search.proquest.com/openview/63a56189863a29b16f5c3aaf250b03b3/1?pqorigsite $=$ gscholar\&cbl=2030636 [Accessed 18 January 2017]. 
Janićijević, N. (2011). Methodological approaches in the research of organizational culture. Economic Annals, LVI(189):69-99. https://doi.org/10.2298/EKA1189069J

Jones, H.B. (1995). The ethical leader: An ascetic construct. Journal of Business Ethics, 14:867-874. https://doi. org/10.1007/BF00872353

Jones, K.B. (2015). Ethical insights of early 21st century corporate leaders. Doctoral dissertation, Walden University, U.S.A.. http://scholarworks.waldenu.edu/cgi/viewcontent.cgi?article $=412 \&$ context $=$ dissertations [Accessed 18 January 2017].

Kacmar, K.M., Andrews, M.C., Harris, K.J. \& Tepper, B.J. (2013). Ethical leadership and subordinate outcomes: The mediating role of organizational politics and the moderating role of political skill. Journal of Business Ethics, 115:33-44. https://doi.org/10.1007/s10551-012-1373-8

Kalshoven, K., Den Hartog, D.N. \& De Hoogh, A.H.B. (2011a). Ethical leadership at work questionnaire (ELW): Development and validation of a multidimensional measure. The Leadership Quarterly, 22:51-69. https://doi.org/10.1016/j.leaqua.2010.12.007

Kalshoven, K., Den Hartog, N. \& De Hoogh, A.H.B. (2011b.) Ethical Leader Behavior and Big Five Factors of Personality. Journal of Business Ethics, 100:349-366. https://doi.org/10.1007/s10551-010-0685-9

Kasthuri, H. (2009). Leading with your soul. Strategic Finance, February:41-51. http://sfmagazine.com/wpcontent/uploads/sfarchive/2009/02/Leading-with-Your-Soul.pdf [Accessed 18 December 2016].

Knights, D. \& O'Leary, M. (2006). Leadership, ethics and responsibility to the other. Journal of Business Ethics, 67:125-137. https://doi.org/10.1007/s10551-006-9008-6

Koning, J. \& Waistell, J. (2012). Identity talk of aspirational ethical leaders. Journal of Business Ethics, 107:65-77. https://doi.org/10.1007/s10551-012-1297-3

Köse, T. \& Köse, S.D. (2016). The effect of ethical leadership on perceived organizational identification: The mediating role of ethical climate. The International Journal of Business \& Management, 4(1):368-374. http:// www.theijbm.com [Accessed 18 December 2016].

Lawton, A. \& Pảez, I. (2015). Developing a framework for ethical leadership. Journal of Business Ethics, 13:639-649. https://doi.org/10.1007/s10551-014-2244-2

Marsh, C. (2013). Business executives' perceptions of ethical leadership and its development. Journal of Business Ethics, 114:565-582. https://doi.org/10.1007/s10551-012-1366-7

Mayer, D.M., Aquino, K., Greenbaum, R.L. \& Kuenzi, M. (2012). Who displays ethical leadership, and why does it matter? An examination of antecedents and consequences of ethical leadership. Academy of Management Journal, 55(1):151-171. https://doi.org/10.5465/amj.2008.0276 [Accessed 17 December 2016].

Mayer, D.M., Kuenzi, M. \& Greenbaum, R.L. (2010). Examining the link between ethical leadership and employee misconduct: The mediating role of ethical climate. Journal of Business Ethics, 95 (Suppl 1):7-16. https://doi.org/10.1007/s10551-011-0794-0

Mihelič, K.K., Lipičnik, B. \& Tekavčič, M. (2010). Ethical leadership. International Journal of Management \& Information Systems, 14(5):31-42. https://doi.org/10.19030/ijmis.v14i5.11

Monahan, K. (2012). A review of literature conserving ethical leadership in organizations. Emerging Leadership Journeys, 5(1):56-66. ISSN 1941-4684, editorelj@regent.edu [Accessed 17 December 2016].

Moreno, C.M. (2010). An approach to ethical communication from the point of view of management responsibilities: The importance of communication in organizations. Ramon Llull Journal of Applied Ethics, 98-108. http://www.raco.cat/index.php/rljae/article/view/270549/358113 [Accessed 15 December 2016].

Murphy, P.E. \& Enderle, G. (1995). Managerial ethical leadership: examples do matter. Business Ethics Quarterly, 5(1):118-129. https://doi.org/10.2307/3857275

Ncube, L.B. \& Wasburn, M.H. (2006). Strategic collaboration for ethical leadership: A mentoring framework for business and organizational decision making. Journal of Leadership and Organizational Studies, 13(1):78-91. https://doi.org/10.1177/10717919070130011001

Northouse, P.G. 2010. Leadership: Theory and practice. 5th edition. Thousand Oaks, C.A.: Sage. 
Obicci, P.A. (2015). Effects of ethical leadership on employee performance in Uganda. Journal of Business Management, 3(1):1-12. http://www.netjournals.org/pdf/NJBM/2015/1/14-024.pdf [Accessed 15 December 2016].

Oktema, S. (2013). The effect of the ethical leadership on perceived organizational justice and organizational identification of the employees: The case of tourism businesses. Journal of Tourism and Gastronomy Studies, 1/3:10-21.

Onorato, M. (2013). An empirical study of unethical leadership and workplace bullying in industry segments. SAM Advanced Management Journal, Spring:4-16. https://www.thefreelibrary.com/An+empirical+study +of+unethical+leadership+and+workplace+bullying+in...-a0338323914 [Accessed 15 December 2016].

Palmer, D.E. (2009). Business leadership: three levels of ethical analysis. Journal of Business Ethics, 88:525-536. https://doi.org/10.1007/s10551-009-0117-x

Palmer, N. (2013). The effects of leader behavior and follower ethical behavior: Examining the mediating roles of ethical efficacy and moral disengagement. Doctoral dissertation, University of Nebraska-Lincoln. http://digitalcommons.unl.edu/cgi/viewcontent.cgi?article=1044\&context=businessdiss [Accessed 15 December 2016].

Parry, K., Mumford, D.M., Bower, I. \&Watts, L.L. (2014). Qualitative and historiometric methods in leadership research: a review of the first 25 years of The Leadership Quarterly. The Leadership Quarterly, 25:132-151. https://doi.org/10.1016/j.leaqua.2013.11.006

Pelletier, K.L. \& Bligh, M.C. (2008). The aftermath of organizational corruption: employee attributions and emotional reactions. Journal of Business Ethics, 80:823-844. https://doi.org/10.1007/s10551-007-9471-8

Pietersen, C. (2016). Research trends in the South African Journal of Human Resource Management: 2003-2012. Paper presented at the SIOPSA Conference, Pretoria, South Africa. http://www.siopsa.org.za [Accessed 15 January 2017].

Pietersen, C. (2017). Organizational culture: A foundational perspective. African Journal of Economic and Management Studies, 18(3):262-273. https://doi.org/10.1108/AJEMS-06-2016-0085

Pietersen, H.J. (2005). Knowledge development in industrial/organizational psychology (South Africa). South African Journal of Industrial Psychology, 31(2):78-85. https://doi.org/10.4102/sajip.v31i2.194

Pietersen, H.J. (2016). The parting of the ways: Foundational orientations in human thought. KR Publishing: South Africa.

Plinio, A.J. (2009). Ethics and leadership. International Journal of Disclosure and Governance, 6(4):277-283. http://0search.ebscohost.com.library.regent.edu/ogin.aspx?direct=true \&db=a9 h\&AN=44824168\&site $=$ eh ost-live [Accessed 15 January 2017]. https://doi.org/10.1057/jdg.2009.20

Plinio, A.J., Young, J.M. \& Lavery, L.M. (2010). The state of ethics in our society: A clear call for action. International Journal of Disclosure \& Governance, 7(3):172-197. https://doi.org/10.1057/jdg.2010.11

Proios, M., Athanailidis, I. \& Arvanitidou, V. (2009). Ethical climate in sports teams. Sports Management International Journal, 5(1):19-38. https://doi.org/10.4127/ch.2009.5.1.19-38

Racelis, A.D. (2010). Relationship between employee perceptions of corporate ethics and organizational culture: An exploratory study. Asia Pacific Management Review, 15(2):251-260.

Resick, C.J., Hanges, P.J., Dickson, M.W. \& Mitchelson, J.K. (2006). A cross-cultural examination of the endorsement of ethical leadership. Journal of Business Ethics, 63:345-359. https://doi.org/10.1007/s10551005-3242-1

Resick, C.J., Martin, G.S., Keating, M.A., Dickson, M.W., Kwan, H.K. \& Peng, C. (2011). What ethical leadership means to me: Asian, American, and European perspectives. Journal of Business Ethics, 101:435-457. https://doi.org/10.1007/s10551-010-0730-8

Robson, C. (2011). Real world research. Oxford: Blackwell.

Ruiz-Palomino, P., Saez-Martınez, F.J. \& Martınez-Canas, R. (2013). Understanding pay satisfaction: Effects of supervisor ethical leadership on job motivating potential influence. Journal of Business Ethics, 118:31-43. https://doi.org/10.1007/s10551-012-1549-2 
Schoeman, C. (2104). Ethics can: Managing workplace ethics: Knowles: Randburg.

Selart, M. \& Johansen, S.T. (2011). Ethical decision making in organizations: The role of leadership stress. Journal of Business Ethics, 99:129-143. https://doi.org/10.1007/s10551-010-0649-0

Shin, Y. (2012). CEO ethical leadership, ethical climate, climate strength, and collective organizational citizenship behavior. Journal of Business Ethics, 108:299-312. https://doi.org/10.1007/s10551-011-1091-7

Smit, A. (2013). Responsible leadership development through management education: A business ethics perspective. African Journal of Business Ethics, 7(2):3-9. https://doi.org/10.4103/1817-7417.123078

Stentz J.E., Clark, V.L.P. \& Matkin, G. S. (2012). Applying mixed methods to leadership research: A review of current practices. The Leadership Quarterly, 23(6):1173-1183. https://doi.org/10.1016/j.leaqua.2012.10.001

Takala, T. (2012). Essays of business and leadership ethics. University of Turka: Finland. http://www.doria.fi/ bitstream/handle/10024/77018/AnnalesB348TakalaDISS.pdf [Accessed 12 February 2017].

Theiri, S. (2013). Relationship between ethical leadership and value creation. Journal of Economics and International Finances, 5(5):212-217.

Van Wart, M. (2014). Contemporary varieties of ethical leadership in organizations. International Journal of Business Administration, 5(5):27-45.

Vogel, L.R. (2012). Leading with hearts and minds: Ethical orientations of educational leadership doctoral students. Values and Ethics in Educational Administration, 10(1):1-12.

Webley, S. \& Werner, A. (2008). Corporate codes of ethics: Necessary but not sufficient. Business Ethics: A European Review, 17(4):405-415. https://doi.org/10.1111/j.1467-8608.2008.00543.x

Yang, C., Ding, C.G., \& Lo, K.W. (2016). Ethical leadership and multidimensional organizational citizenship behaviors: The mediating effects of self-efficacy, respect, and leader-member exchange. Group and Organization Management, 41(3):343-374. https://doi.org/10.1177/1059601115594973

Yates, L.A. (2014). Exploring the relationship of ethical leadership with job satisfaction, organizational commitment, and organizational citizenship behavior. The Journal of Values-Based Leadership, 7(1):1-15. http://scholar.valpo.edu/jvbl/vol7/iss1/4 [Accessed 12 February 2017].

Yukl, G. (2006). Leadership in organizations. Pearson Prentice Hall: New Jersey.

Yukl, G., Mahsud, R., Hassan, S. \& Prussia, G.E. (2013). An improved measure of ethical leadership. Journal of Leadership \& Organisational Studies, 20(1):38-48. https://doi.org/10.1177/1548051811429352

Zain-Ul-Aabdeen, Khan, M., Khan, H.G.M., Farooq, H.Q., Salman, M. \& Ruzwan, M. (2016). The impact of ethical leadership, leadership effectiveness, work related stress and turnover intention on the organizational commitment. International Journal of Economics and Business Administration, 2(2):714. http://www.aisience.org/journal/ijeba [Accessed 10 February 2017].

Zhu, W. (2008). The effect of leadership on follower moral identity: The mediating role of psychological empowerment. Leadership Review, 8:62-73.

Zhu, W., May, D.R. \& Avolio, B.J. (2004). The impact of ethical leadership behavior on employee outcomes: The roles of psychological empowerment and authenticity. Journal of Leadership and Organizational Studies, 11(1):17-26. https://doi.org/10.1177/107179190401100104 